Article

\title{
Experiences and Expectations of International Students at Historically Black Colleges and Universities: An Interpretative Phenomenological Analysis
}

\author{
Luis Miguel Dos Santos
}

Woosong Language Institute, Woosong University, Daejeon 34514, Korea; luisdossantos@woosong.org

Received: 12 June 2019; Accepted: 16 July 2019; Published: 19 July 2019

\begin{abstract}
International students are the most important population in the American higher education system, particularly for students from different cultural backgrounds. Besides research-based universities, comprehensive universities, and liberal arts colleges, historically black colleges and universities have the traditions to provide an equal learning environment to minorities, including international students. This study aimed to understand the academic experiences and expectations of Chinese international students enrolled at historically black colleges and universities in the Southeastern parts of the United States from the lens of neo-racism. One research question guided this study, which was: How would Chinese international university students describe their academic learning experience, expectations, stress, and difficulties at one of the historically black colleges and universities? The interpretative phenomenological analysis (IPA) was employed to explore the academic experience, difficulties, stress, and lived stories of their academic voyage at one of the historically black colleges and universities in the United States. The findings indicated that discrimination based on skin color, nationality, and race, the gaps in academic expectations, and social unfairness of internship opportunities are still significant. The result indicated the directions and recommendations for leaders, policymakers, school administrators, and related professionals to redesign the current university planning and related counselling services to not only international students but all minority people.
\end{abstract}

Keywords: Asian international students; Chinese international students; college student counselling; discrimination; higher education; historically black colleges and universities; international students; Interpretative phenomenological analysis; minority students

\section{Introduction}

The United States of America is a cosmopolitan country where citizens from around the globe come to live, study, work, and invest their time. American colleges and universities always welcome international and immigrated students to study and enjoy a rigorous education [1,2]. According to a recent report [3], there were 1,184,735 active internationals in the United States for educational purposes in May 2017. Within this population, 33\% were pursuing an undergraduate degree, 31\% were pursuing a master's degree, and $12 \%$ were doctoral students. As for the ethnic background, $77 \%$ of the total came from Asia, an increase of $2.1 \%$ from the previous year. Chinese $(362,368)$ and Indian $(206,698)$ students were the largest populations among the international student groups in 2017. It is also worth noting that most international students tend to enroll at larger, well-known, and urban universities. Currently, New York City, Los Angeles, and Boston are the top-three American cities with the largest international student populations [4]. 
Although Asian communities and student learning groups are not hard to find in the United States, communication difficulties as well as unfamiliar cultural diversity, ethnic background, and living conditions and standards are some of the elements that international students must face during their time there $[5,6]$. Some international community members believe that living in a different cultural environment may increase their competition and self-esteem, leading to personal enhancement. On the other hand, some international students may face depression and feelings of anxiety [7-9]. The experience of studying at American colleges and universities could be simultaneously exciting and annoying for international students, particularly for Asian students who do not have similar cultural backgrounds $[10,11]$. For states, colleges, and universities with a large number of overseas immigrants and international students, globalized learning programs and on-campus facilities should be well established [12]. However, in some states, colleges, and universities with more specific missions, international students may face more considerable difficulties than if at other urban university campuses [3,6,12-14].

As a result, American colleges and universities seek plans and solutions to meet the challenges of assisting local and international students with special needs and difficulties to foster their successful higher education experience in the United States [15]. For more than a century, Asian international students have come to the United States for vocational training, postsecondary education, and graduate education. First, in recent decades, international students have enrolled in American colleges and universities due to limitations in their own countries' universities' majors and expertise [16]. For example, some landlocked countries may not offer majors in marine sciences and oceanology. Second, a large number of students and their parents would like to experience globalization, internationalization, inter-cultural experience, and personal enhancement from both internal and external developments [17]. Third, students seek to gain advanced language and cultural understanding and abilities. It is not hard to understand that the English language is one of the most common and essential languages in the field of business and commerce. The Chinese language is currently the second most spoken language in the world [18]. Therefore, Chinese students can gain exceptional opportunities after university graduation if they can master both English and Chinese [19-22]. Fourth, university graduates may have chances to seek international work experience and career development after graduation. Currently, a large number of American organizations and business partners have established factories and business centers in the East Asian region, particularly the greater China region. East Asian students, particularly Chinese students, could gain international experience in these organizations if they participate in their internship programs [23]. Fifth, unlike other countries with limited choices of universities and majors, the United States has more than 3,000 colleges and universities, from community colleges to doctoral research-based universities, for potential enrollment. These reasons significantly increase the motivations for international students, particularly Chinese international students, to start their college or university experience in the United States after secondary school graduation [24].

Recently, a report [25] indicated that over $70 \%$ of the Chinese international students in the United States were facing stresses and cultural concerns due to the cultural differences, language barriers, and more importantly, discriminations from other American people and students. Due to the traditions and cultural expectations, Chinese international students usually do not seek counselling services because of social stigma. As a result, negative experiences and expectations of their educational voyage may occur due to the negative emotional feeling and overall experience of the society [26].

Scholars [27] have indicated that international students might encounter discriminations due to language and behavioral differences. The Chinese population is among the largest community internationally. As a result, Chinese international students tend to form their social communities and supporting groups physically and mentally due to the population. In the United States, such Chinese supporting groups were not uncommon in urban and metropolitan cities and regions, such as New York City and Chicago. Due to the supporting from people who share similar characteristics, Chinese people and Chinese international students tend to seek support from those who can share similar backgrounds and understanding $[9,25,28-31]$. 
Based on the ideas of collectivism, a large number of Chinese international students tend to enroll at one of the colleges and universities where Chinese communities, Chinese supporting groups, and Chinatown are easily found. As a result, colleges and universities located in rural and mid-west regions of the United States usually cannot attract Chinese-American students and Chinese international students for enrollments. Significantly, historically black colleges and universities which focus on the services for African American citizens do not have attractions to Chinese international students $[9,25,29,30,32]$.

Historically black colleges and universities offer supportive higher education communities for minority students, particularly African American students [33]. For decades, research studies explored the academic and outcome differences between historically black colleges and universities and other predominantly White institutions [34]. Although reports indicated that both historically black colleges and universities and predominantly white institutions provide the same level of education to their students, non-African American students tend not to attend these universities [35].

Based on the current database, the researcher cannot locate any research studies about the enrollment issues, experience, and expectation of Chinese international students at the historically black colleges and universities. It is important to understand the experiences of these particular groups of populations because recent research studies have indicated that historically black colleges and universities could attract more non-African American populations to their programs [36]. While more African American students are attending predominantly white institutions, the researcher would like to understand why non-African American students seek enrollments and admission into historically black colleges and universities, particularly Chinese international students [35].

Therefore, in the current study, the researcher mainly focused on Chinese international university students' lived stories and experiences of enrolling at historically black colleges and universities in the Southeastern part of the United States. There are four reasons why this particular group of Chinese international university students were examined in this study. First, Asian students form the largest international and/or minority student population in the United States [3]. It is worth noting that Asian international students are not Asian American residents. Asian American residents usually understand the westernized and American culture as they are American citizens or long-term residents. Asian international students, however, are foreigners who seek education in the United States. Their language, cultural background, understanding, habits, and living styles are not the same as those of Asian American residents in American society [37].

Second, research studies indicate that Asian students usually face cultural stress and difficulties more than European students. Due to the language barrier and the differences in living styles and cultural background, Asian international students could face challenges in the United States and American colleges and universities [38].

Third, as Asian students and Asian international students tend to enroll at large and well-established urban universities, this study is interested in why the targeted participants decided to enroll at historically black universities [39].

Fourth, research studies focusing on non-black students at historically black colleges and universities, not to mention the experiences of Chinese international university students, are limited [40,41].

This study aimed to understand the experience of Chinese international university students enrolled at historically black colleges and universities in the Southeastern part of the United States. Therefore, the current study posed a focus and a research question:

1. How would Chinese international university students describe their academic learning experience, expectations, stress, and difficulties at one of the historically black colleges and universities? This will help to inform university administrators to reform and develop their colleges and universities in line with globalization and to create international campuses. 


\section{Theoretical Framework: The Neo-Racism}

Neo-racism refers to another type of racism based on the individuals' place of origin with their skin color(s) [42]. This theory was significantly used in different studies with the focuses on international students, minorities, women, diaspora, and social stigma. The ideas of social level and social class gradually become one of the most significant elements of discriminations in contemporary society due to the ideas of globalization and international movements [43]. Currently, a large number of neo-racism studies in the field of higher education tend to focus on the relationship between their social status, economic status, skin color(s), and place of origin. The applications of neo-racism allow the researcher to understand the experience and expectation of Chinese international students who completed their university degree at one of the historically black colleges and universities in the United States. Unlike other traditional colleges and universities in the United States, historically black colleges and universities mainly focus on the services and opportunities for minority students, particularly for African American citizens. Although historically black colleges and universities focus on the rights for minority students, all students regardless of their background may enroll for educational purposes. Due to the unique background of historically black colleges and universities, the theory of neo-racism is useful and meaningful to explore and understand the experience and expectation of Chinese international students [44].

\section{Methodology}

A qualitative research design was employed for this study $[45,46]$. This design allows the researcher to gain the understanding, lived stories, and knowledge about the social problems and phenomena about how Chinese international college and university students describe their learning experience and lived stories at one of the historically black colleges and universities in the United States.

\subsection{Interpretative Phenomenological Analysis}

An interpretative phenomenological analysis (IPA) was employed [47]. Phenomenology, hermeneutics, and ideography are three major principles of IPA for researchers to develop an understanding of the background and inner world of participants, which are grounded and are yet to be established beyond their understanding, sense, perspective, and conceptualization [48]. As the foundational perspective of IPA aims to study how individuals make sense of their personal and social world, within the research study, the researcher assisted, aimed, and planned to guide the participants to share their lived stories and express the sense-making process with detailed descriptions [49]. IPA is also a useful tool to understand explored topics and studies [47-50]. Therefore, IPA would be appropriate to this study because the experience and expectations of Chinese international students at historically black colleges and universities are not widely examined in the current database.

\subsection{Participants and Data Collection}

Five recent university graduates from five $(\mathrm{N}=5)$ different historically black colleges and universities were invited to this study. All of the participants agreed to participate in this study. Given that IPA focuses on providing an interpretative and detailed direction of participants' lived stories and experiences, scholars [47] suggested a limited number of participants (less than 10) with information collected from two sessions of semi-structured interviews and one session of focus group activity would be appropriate for studies in IPA. All the participants are members of a non-profit organization in Hong Kong, China, which provides a sharing community for Asian students who studied their academic degree in the United States. It is worth noting that for this particular research study, all of the participants are Hong Kong Permanent Residents who have received their primary and secondary school education at one of the K-12 institutions in Hong Kong, China. The voices, sharing, and lived stories, however, tended to be the opinions from the understanding of the residents in Hong Kong, China. 
As for the number of the participants, according to the handbook of IPA study [47], IPA studies should not recruit more than 10 participants in order to perform the rich and in-depth understanding. The researcher decided to recruit five qualified participants for this study. Although the researcher intended to recruit 10 participants in order to exercise the wider pictures of this direction, the researcher could not recruit enough participants due to the narrowed focus and the nature of historically black colleges and universities. Therefore, five participants would be the maximum number for the current situation. The background and the procedure of recruitment are outlined in the following part.

Based on the research question, two separate interview protocols and one focus group activity protocol were developed to explore the significant aspects of this research. First, the researcher interviewed each of the participants individually in a semi-structured, one-on-one, face-to-face in-depth interview with each interview lasting 90-120 min and being consistent with interview criteria. Second, after the researcher completed the first session of the semi-structured interview, a second session of the semi-structured interview for each participant was conducted with each interview lasting 90-120 $\mathrm{min}$. In fact, the structure of the two interview sessions was important. Unlike sharing general ideas and understanding of a set of social problems, the IPA research studies tended to capture individuals' lived stories, personal experience, personal background, and sensitive information. If the researcher does not have any relationships between each of the participants, the participant may not share the real feedback and lived stories to the researcher. For example, some experiences of discriminations could be sensitive due to privacy and unpleasant feelings. If the researcher cannot capture these feedback and experiences, the results of this research study may not be rich and colorful. It is vital to note that the first session of the semi-structured interview tended to establish the interpersonal relationship to each participant. After both the researcher and participants understood and knew each other, the participants were more likely to share in-depth lived stories to the researcher.

After 10 sessions of the semi-structured interview, the researcher further invited the five participants to share their understanding and lived stories under the controls of a focus group activity. During the focus group activity, the researcher asked several open-ended questions and led the activity. The participants shared, echoed, and answered the experience and lived stories from each other. The focus group activity lasted for $90 \mathrm{~min}$. During the sessions, a digital audio-recorder was used to collect all the information. The participants' personal information is listed in Table 1. All of the conversations were digitally recorded, transcribed, and returned (i.e., for member checking) to the participants for validation of the content. Once the participants approved their transcripts, the data were analyzed employing the MAXQDA v.11 qualitative data analysis software.

Table 1. Demographics of the participants.

\begin{tabular}{ccccc}
\hline Name & School & Location & Years in USA & Degree and Major \\
\hline Amy & H-University & Texas & 4 & Bachelor of Art (Elementary Education) \\
Betty & X-University & Louisiana & 4 & Bachelor of Art (Social Studies Education) \\
Calvin & F-University & Florida & 4 & Bachelor of Science (Biology Education) \\
David & A-University & Georgia & 5 & Bachelor of Science (Chemistry Education) \\
Eddie & P-University & Arkansas & 4 & Bachelor of Science (Mathematics Education) \\
\hline
\end{tabular}

\subsection{Data Analysis}

An inductive approach was employed for this study [51]. The inductive approach allows the researcher to understand the sharing of experiences and lived stories among the Chinese international students enrolled at one of the historically black colleges and universities in the United States. The researcher followed a general inductive approach to narrow the large-size transcript into first-level themes by employing the open coding technique [46,52]. The general inductive approach [51] suggested that first-level themes are usually involved with unorganized themes and information. Therefore, further narrowing should be conducted by the axial coding technique. After the completion of the axial coding procedure, the second-level themes were categorized for reporting. 


\subsection{Participants Recruitment and Research Site Access}

This study involved one single site, which was a non-profit organization located in Hong Kong, China. As the researcher is an active member of the non-profit organization, the researcher asked the administrators to invite potential participants from a monthly electronic newsletter via emails. Fortunately, five members of the organization met the criteria and agreed to participate. Therefore, the researcher contacted the potential participants through a printed letter for the invitation. The letter provided information including the mission and significance of the study, the nature of the data collection procedure, a declaration about their voluntary participation or non-participation, the protection of privacy, and a risk statement. Within five days, all participants contacted the researcher for the interview sessions.

All of the interview sessions and the focus group activities were conducted in a private conference room at the non-profit organization. For the individual interview sessions, only the researcher and participant were in the conference room for privacy. For the focus group activity, the five participants and the researcher were in the conference room.

\subsection{Protection of Subjects}

The protection of human subjects is vital to this study. One main concern is the protection of participants' identities. Therefore, the researcher made every effort to protect the identities of all participants and the research site by masking their names. As a result, all participants were given a pseudonym for reporting. Also, all related documents, electronic materials, and computer were locked in a password-protected cabinet. Only the researcher has the rights to access. After the study was completed, all the materials and information were destroyed and deleted due to privacy. No related information will be disclosed $[45,46,52]$.

\section{Findings}

This study followed the IPA research design [47-49]. Through this qualitative inquiry, the researcher was able to inductively analyze the data and build themes, discover the social phenomenon, and discuss the findings in order to understand how Chinese international university students describe their lived stories and experiences while enrolled at historically black colleges and universities in the United States. By analyzing the data as a whole, the researcher was able to identify several common themes. The analysis of the in-depth and semi-structured interviews yielded three superordinate-themes and three sub-themes under the theoretical framework of neo-racism [43,44], as shown in Table 2. Almost all Chinese international university students enrolled at historically black colleges and universities engaged with almost all common characteristics and experiences. It is worth noting that under the lens of neo-racism [42-44], in this research study, the researcher intended to capture the sharing, feedback, and opinions about the academic experience and expectation of Chinese international university students who enrolled at one of the historically black colleges and universities in the United States.

Table 2. The themes and subthemes of the findings.

\begin{tabular}{l} 
Themes and Subthemes \\
\hline 1. Discrimination from Other People at School \\
1.1 Discrimination of Language Usage from American Classmates \\
1.2 Discrimination of Personal Characteristics from American Classmates \\
2. Academic Expectations are Less Rigorous \\
2.1 The Overall Learning Motivation is Lower than Expectation \\
3. Less Employment and Internship Opportunities than Other Normal Colleges and Universities \\
\hline
\end{tabular}

Unlike other research studies and reports $[9,11,27]$ intended to capture the psychological problems, stresses, coping strategies, and career decisions from international students in the United States in general, the themes and subthemes from this research study categorized the unchangeable elements 
which were connected to the primary concerns of neo-racism. Based on the transcripts, discriminations of their skin color(s), nationalities, use of languages, the views of other classmates, and opportunities due to the status of the historically black colleges and universities have been captured. The following parts explained how the elements of neo-racism applied to the themes and findings.

\subsection{Discrimination from Other People at School}

Discrimination exists in all parts of society. People can be discriminated against due to their skin color(s), language, place of birth, nationality, gender, sexual orientation, etc. At historically black colleges and universities, international students from all other countries are expected to experience an open-minded environment. However, the Chinese international university students shared difficulties in two areas, related to English language learning, skin color(s), and place of origin, which completely reflected the theoretical framework of neo-racism [44]. The following parts outline and conclude how neo-racism is reflected.

\subsubsection{Discrimination of Language Usage from American Classmates}

Proficiency in English language usage could be a key tool for university students, mainly in exchanging knowledge and sharing ideas $[53,54]$. In lectures requiring peer discussion and group work, participants reported that some classmates refused to form groups with them. For example, Amy had graduated from an English-based school in Hong Kong, China and had excellent English language proficiency but a strong accent. She shared her experience from the first three years of university, that her classmates discriminated against her because of her accent, saying,

My classmates always made fun of my language during freshman, sophomore, and junior year. My accent does not affect my language usage, but many of them like to laugh at people with disadvantages.

Betty also shared a very similar experience during her university life as well, saying, "I especially disliked some courses in which I had to study with freshman students. Newcomers and transferred students without much experience with international students are not very open-minded." Both participants expressed that other classmates laughed at them because of their accents. Three other participants expressed negative experiences toward African American classmates due to their English proficiency. Calvin said that, "English is my second language. But I am able to handle the language without any difficulties. But my classmates just liked to laugh at my speaking and listening skills." David also expressed a similar experience, saying, "during my first year at school, people did not like me because of my language problem. I could only make friends with people at the writing center and English as a Second Language classmates." Eddie also commented on this, saying, "some people are not ready to accept classmates and friends from other countries. The world is large enough to embrace all other languages and cultures other than American culture and English language. American students should learn to accept this globalization."

In short, the use of English language, accent, and place of origin were some of the biggest concerns of Chinese international university students at one of the historically black colleges and universities. First, several have shared that the accent of their English served as the point. Although the English accents do not relate to their academic outcomes and achievements, some classmates refused to form project groups with them due to the use of language. Second, although the participants did not express the ideas about discriminations of their nationalities and place of origin directly to the researcher, many of the opinions and sharing reflected the ideas of their place of origin and nationalities.

\subsubsection{Discrimination of Personal Characteristics from American Classmates}

Like other minorities in the United States, African Americans, Asian Americans, Latin Americans, and Native Americans are considered minorities based on their ethnicity, place of origin, skin color(s), and spoken languages based on the directions of neo-racism [42,43,55]. More importantly, besides language barriers and accents, Chinese international university students particularly faced similar 
negative situations due to their skin color(s), nationality, etc. The following part employs the neo-racism as the lens to outline the findings and sharing from the participants.

Betty and Calvin expressed several experiences of being discriminated against by African American classmates. It is worth noting that although African American classmates are considered as minorities based on the lens of neo-racism, a number of African Americans discriminated against other ethical and racial minorities based on their skin color(s), place of origin, nationalities, and personal characteristics, as Betty said, "I understood this is a historically black university which has a lot of protection plans for African students. But as a minority, Asian and female ... I could feel the discrimination on campus toward Asians and international students." In the case of Betty, Betty expressed her personal stories about how she was discriminated by other African American classmates based on her skin color(s), ethical background, and gender $[43,44]$.

Besides the sharing from Betty, Calvin shared a serious situation which he reported to the international student office, saying,

During my sophomore year at the university, an African American classmate asked me to go back to Asia and said that I should not stay in the United States because of my skin color and nationality ... in front of the classroom and groups of classmates. I was very surprised that minority students discriminate against other minorities. A Caucasian female classmate recorded this horrible conversation and went to the international student office with me.

The above stories reflected the directions of neo-racism due to individuals' personal characteristics, such as skin color(s), spoken language, place of origin, and nationality. Both participants were surprised that minorities in the United States discriminated other minorities based on the personal characteristics that no one could change. Therefore, it is worth noting that giving discriminations toward minorities was not only the behaviors of white people but everyone in the United States [43,44].

These lived experiences indicate that even though American college and university campuses are supposedly free for all types of students to pursue their education and future fairly, discrimination still persists. Amy, David, and Eddie experienced similar discriminatory situations from other non-African American classmates on campus. Both Amy and David were discriminated against by Caucasian American classmates because of their skin color(s) and nationality. Amy shared that, "I lived in the dorm with two other Caucasian American classmates during freshman year. They used a Spanish swear word to describe me during their conversations. I did not understand the word at first due to the language barrier". David also experienced several situations and reported one to the police, in which "three Caucasian Americans always asked me why I don't have the pigtail hair as described by the history textbook." Eddie indicated that several of his classmates used international and political situations to laugh at him, saying, "some Caucasian American classmates always told me to go back to Asia and that the United States does not welcome Asian students to stay." Particularly, the personal characteristics, such as skin color(s) and nationality, were some of the elements that were being discriminated. For example, several participants were discriminated due to their skin color(s), the historical outlooks of their people, and even the political situations of their place of origin. Such behaviors, in fact, reflected how scholars reported the typical discriminations based on the lens of neo-racism [42-44].

In short, all participants expressed multiple experiences of discrimination that highly influenced their academic experience at the university. Even though these situations occurred infrequently, this negative behavior and discrimination were enough to destroy the positive spirit of America for these students. It is worth noting that not only historically black colleges and universities, but also American colleges and universities, should be more open-minded regarding minorities and international students due to their institutional purposes and mission goals because, unfortunately, the results from this study's participants do not reflect the successful attainment of these goals. 


\subsection{Academic Expectations are Less Rigorous}

When sharing their views about academic reputation and expectations at historically black colleges and universities, all of the participants believed the academic expectations at historically black colleges and universities were lower than at other universities in the United States. First, all of the participants expressed the ideas of "workload" and "expectations from lecturers" more than twice during the interviews. More importantly, all participants indicated that their university lecturers and instructors at the historically black colleges and universities accepted, expected, and provided lower-level academic expectations to minorities students, including but not limited to African Americans, Asian Americans, Latino Americans, Native Americans, international students, and English as a Second Language students etc. Although the rubrics and standard set the leveling of individual courses, some instructors tended to adjust some requirements based on students' personal characteristics, as shared by the participants. It was surprising that university instructors and lecturers adjusted some elements based on some unchangeable status, which reflected the ideas of neo-racism [42-44]. The following part explains and outlines some key lived stories of this situation.

Amy and Eddie had participated in exchange programs with other colleges and universities in the United States. During the junior year, Amy participated in an exchange program with an urban and top-tier university in New York City. Amy shared, "when I am able to compare my university to my exchange university in New York City, I can tell that the expectations from my university are much lower than normal." Eddie also shared similar ideas, noting that, "the expectations from my lecturers are similar to community college standard ... I wish I can learn and work as a university ... instead of a vocational school student ..." The researcher further asked about how they can evaluate the differences between their home and host universities in the term of levels and difficulties. Both of them shared some lived stories, Amy expressed that several of her lecturers and instructors adjusted the coursework, workload, and requirements due to the personal characteristics of the student population, sharing,

I have asked my lecturer about how come the coursework requirements were not the same between two sections with the same course title ... my lecturer told me because my section was full of Asian and international students ... although international students may need more and additional help ... how can you adjust the reading and knowledge based on our nationality

On the same hand, Eddie indicated that one of his lecturers believed the international students should only study at the evening sections with returning and adult students due to the language barriers and cultural differences, sharing,

... he or she believed ESL students and international students were not at the same level ... even if I tried my best ... my lecturer just expected the lower from us ... or not just us, but all minorities students at the historically black colleges and universities... I am not satisfied with the qualities of the school staff and the school itself...

The above stories were unexpected as some lecturers believed international students and ESL students should be given the lower-level requirements, academic experience, and expectations due to their personal background and characteristics [42-44]. Although the participants had reported the situations to the appropriate offices, no further actions were taken.

Betty, Calvin, and David participated in exchange programs in three different European universities in Demark, the United Kingdom, and Sweden. They expressed positive experiences regarding their partnered universities but negative expressions for their own university. The negative expressions had in common similar negative ideas about academic standard and workload. Betty shared, "my expectation of workload for university students is at least 50 pages per course per week. The partnered university in Denmark satisfied my expectation, but the overall expectations from lectures at my university were somehow below my own expectation." Calvin shared, "the conversations between classmates and professors are much more intelligent in the partnered university." David shared ideas 
about other international students at the partnered university, saying, "the partnered university in Sweden had more than 1,000 international and minorities students on campus. All students were there to exchange high-level ideas and knowledge. The learning environments were much more similar to university standard." Although the above participants did not directly express their concerns about the racism and discrimination, the researcher might indicate the participants disliked and disagreed with their academic experience and expectations at their home universities.

The Overall Learning Motivation Is Lower than Expectation

This subtheme is divided into two directions, which are: 1. less motivation for knowledge sharing in the classroom, and 2. less learning motivation of classmates. All participants expressed similar experiences regarding both directions. It is worth noting that the subthemes and categories were merged based on the lens of neo-racism.

First, regarding the idea of less motivation for knowledge sharing in the classroom, Amy shared the strongest negative experience,

... no one in all my courses liked to share any opinions during lectures ... some of my professors assigned readings and assignments before the end of each class, but no one read and did the assignments and reading before the next class started. However, many of my professors did not know how to manage the lectures too ... every time when the lecturers met with silence from the class, the only thing they could do was call on me to respond. I felt very uncomfortable when other classmates received the same grade as me.

After Amy shared this experience, the researcher further asked why the professors and instructors liked to ask her for answers. Amy believed that was because she was the only non-African American or black student in her courses. She further indicated that due to her skin color(s) and nationality, a higher expectation of reading and workload were assigned.

Calvin also complained about how classroom management and professors' reactions made him uncomfortable, sharing,

I could not comment much about the situations at other universities, but only my university. Students just did not like to read the assigned reading before lectures. My classmates always completed the reading five minutes before the lecture, or sometimes during class. This learning attitude applied to all types of students at the university.

Second, regarding the idea of less learning motivation of classmates, Betty, David, and Eddie expressed that all of their full-time classmates had more than $20 \mathrm{~h}$ of part-time work after lectures. Betty shared, "during my day-time classes, all my classmates were full-time students. But the motivation to learn was much less than that to work at part-time jobs." David shared another idea regarding the graduation rate at his university, remarking,

The graduation rate for my university is less than $20 \%$. I understand not all students could afford the tuition fees and living costs for the entire university period. Most of my classmates in my program worked at least $20 \mathrm{~h}$ during their free time. However, we are full-time students with 12-15 credit-hours per week. How can the working part-time hours exceed the academic credit-hours? Are they full-time students or full-time workers or what? If they have family issues or other responsibilities, that would be a different story. But all of them are full-time students.

The researcher further asked about how his classmates viewed his status as full-time student and full-time international student in his department. David indicated that most of his classmates discriminated him based on his status of international student, saying, "my classmates always forced me to read the reading and assignments as I am the only full-time student without working hours ... but more importantly, they forced me to do something because of my nationality ..."

Eddie shared another idea about course retaking, explaining, 
Not all students are good at interdisciplinary subjects, meaning not all students can handle literature, science, math, foreign languages, and social sciences at once. But I do not understand why the retaking or failure rate of my college is much higher than my expectations. Receiving a failed grade is not uncommon in my college. The college recorded that $40 \%$ of students needed to retake at least six credit-hours per semester ... retaking courses is normal practice within this learning environment.

In short, all participants indicated different types of negative academic expectations and learning motivations during their academic voyage at historically black colleges and universities. The negative opinions mainly focused on classroom management, learning motivation of classmates, balance between learning and working, and university graduation rate. But more importantly, based on the lens of neo-racism [42-44], all participants indicated discrimination or unbalanced workload and assignment due to their skin color(s), nationality, and status of international student.

\subsection{Less Employment and Internship Opportunities than Other Normal Colleges and Universities}

Four of the participants expressed that historically black colleges and universities provided fewer employment and internship opportunities than other colleges and universities. Amy and Betty indicated that the university career service did not provide many career-oriented workshops and preparatory training for junior and senior level students. Amy shared,

I went to the career center twice. However, the career center was very passive. The center does not actively seek career and internship opportunities from potential employers. During the last year at university, all of our classmates needed to find an internship organization to meet the requirement. However, the career service could only direct us to search for internships online with no help. When we were looking for resume and cover letter samples, the only comments were to look at websites.

The researcher further asked about any additional stories and experiences in the career center, Amy further shared, "as I am not an African American or black college student, the center staff somehow did not understand how to guide me ... also, as I am an international student, not all staff understood how to apply for the international working visa ... " It is important noting that the status of international student and nationality somehow limited their opportunities for the use of the career center.

Betty shared a similar experience:

Before I started my last year at university, I had never worked before. Therefore, I did not have any experience of writing resumes and cover letters. Besides asking friends and professors, I knew my university had a career service I could use. But the career service works like a counselling center instead of a career service. I took several psychological tests and questionnaires during the first and second visits to the center, but I never received help or training for writing resumes and cover letters.

Calvin and Eddie shared different experiences from Amy and Betty, but their experiences were also negative. Both believed the homogeneity of career opportunities at historically black colleges and universities meant that these opportunities were not applicable to non-black students. Calvin shared,

The career center collected and combined more than 100 potential positions for recent university graduates. However, most of the opportunities required bi-lingual (English-Spanish) skills or were for non-profit organizations for minority groups in the South and/or lower-level positions for non-degree holders. I cannot blame the career center because no potential employers sent opportunities to my university.

Eddie shared another idea about the career service. However, he also complained about the homogeneity of potential career choices, saying,

I understand that, historically, black college and university students may be at a disadvantage when seeking graduate careers. Therefore, I only went to the career service for workshop preparation. But most of the career service workers are African Americans. They always encourage our graduates to 
work for organizations with minority groups' protections. But as for myself, I want to label myself as a minority. Since the career service can only provide or focus on opportunities for minorities' rights and caring, I decided to not use this service.

The theoretical framework [42-44] allowed the researcher to understand and explore the academic experience and expectation of Chinese international students at one of the historically black colleges and universities in the United States. Amy, Betty, Calvin, and Eddie shared similar ideas about how the career services at their historically black colleges and universities assisted or did not assist their career seeking processes. The opinions focused on the themes: less prepared for career-oriented workshops and homogeneity of career choice. Both of these reduced the interest of upper-class students and recent university graduates in seeking to set their careers in the right direction before and after university graduation. Although different participants shared different lived stories and experience, all participants expressed their skin color(s), nationality, and status of international student limited their opportunities and career counselling services at their university. More importantly, some participants expressed that the discriminations were even given by their school professionals and staff due to their personal characteristics and nationality, for example, the status of international students, visa types, and even the use of languages.

In conclusion, the international student population has created an inter-racial and inter-cultural diversity for the American community. In recent decades, international students have become one of the most critical assets for a large number of colleges and universities. At historically black colleges and universities, a tradition of protection and caring mission have served these institutions for minorities and disabled students. However, this study's findings also indicate that all of the participating Chinese international university students enrolled at historically black colleges and universities tended to have negative experiences and lived stories instead of positive feelings. Based on the findings of this study, three main themes have been identified: Chinese international university students had negative experiences regarding discrimination on campus, the institutions' low academic expectations of students, and employment difficulties. In Chapter four, the researcher expands the data analysis and relates the common themes for answering the research question.

\section{Discussion}

According to the results of the study, the participants had already completed their undergraduate degree at one of the historically black colleges and universities in the Southeastern part of the United States. Surprisingly, all of the participants shared negative experiences, lived stories, and opinions about their educational voyage in the United States. This research study applied the theoretical framework of neo-racism as the lens [42-44] to understand and explore the academic experience and expectation of Chinese international students at one of the historically black colleges and universities. Although most of the American colleges and universities have established different sets of policies and plans for minority protections, Chinese international students expressed the feeling of discriminations due to their skin color(s), nationality, place of origin, and status of international student.

\subsection{Chinese International University Students Described Academic Experience and Expectation at One of the Historically Black Colleges and Universities}

Surprisingly, all five of the participants reported similar negative learning experiences, stress, and difficulties at different historically black colleges and universities. In particular, difficulties and stresses with discrimination due to skin color(s), nationality, place of origin, use of language, and status of international student $[43,44]$ from other classmates are the most significant challenges Chinese international university students experience during their education voyage at one of the historically black colleges and universities in the United States [19,20,56,57]. Although studies [7] suggested that international students may face language barriers and problems due to the limited English language proficiency, language issues are not the most significant concerns as all five of these participants received their primary and secondary school education at one of the English language-oriented schools 
in Hong Kong, China. The language usage and proficiency must not be their primary problems in communications and interpersonal interactions. The participants shared three main challenges during the academic voyage in the United States, which were discrimination from other people at school, academic expectation concerns, and career opportunities. It is worth noting that based on the sharing and opinions from the participants, the skin color(s), nationality, place of origin, use of language, and status of international student were the primary concerns which reflected the theoretical framework of neo-racism. Although most of the American colleges and universities tried their best to establish plans for minority students, the notions of discrimination continued. More importantly, at historically black colleges and universities which are established for minority students, the discrimination of skin color(s), place of origin, use of language, and nationality were found. The following parts discuss the findings of this research study.

\subsubsection{Discrimination}

Discrimination is one of the significant challenges all over the United States, particularly for minorities and international students [1,58]. Although some of the members of the public may believe colleges and universities should establish a safe and equal environment for students, particularly for historically black colleges and universities which mainly serve the minority people in the United States, international students found that the discrimination problems are still significant on campuses $[4,11,39]$. In the literature, although the previous literature argued that language barriers are the most significant issue within the American university system for international students, the participants advocated that personal characteristics are the most significant problems. In this study, all five participants expressed that they had received satisfied English language test scores (i.e., TOEFL or Test of English as a Foreign Language and IELTS or International English Language Testing System) for the admission criteria, their classmates tended to laugh at the accent of their English language. Amy said that "some classmates intended to ignore my sharing due to my accent ... " These participants' situations should not be standalone cases, but the general issues and problems for a large number of international students in the United States. From the viewpoints between neo-racism and use of language, the participants advocated that their classmates at the historically black colleges and universities discriminated against them based on their use of language, and the accent of the language. This research study discovered that although African Americans and students who decided to enroll at historically black colleges and universities always advocate the ideas of social equalities and fairness, some school professionals and students continue to exercise discriminations to other minority students, in this case, Chinese international students [43,44,59].

Second, all five participants also expressed that their personal characteristics, such as skin color, place of origin, and nationality, are some of the challenges during their academic voyage at one of the historically black colleges and universities. Unlike other regular and standardized colleges and universities, historically black colleges and universities tend to provide a safe and equal environment for minority people in the United States for higher education opportunities. It is surprising that international students, particularly students from Hong Kong, China, believed other American classmates discriminated their personal characteristics due to their skin color and nationality [7]. Therefore, it is shown that although the policy and regulation of some American colleges and universities advocated for the protections and fairness for all minority people in the United States, the problems of racial and background discriminations are not uncommon on American campuses $[43,44,59]$.

\subsubsection{Academic Expectation}

Third, all participants advocated that their enrolled colleges and universities did not meet their academic expectations due to the low-motivation and low-expectation of their professors, schools, and classmates. Although the academic standard does not directly relate to the events of discrimination, all participants expressed several related situations due to their personal characteristics $[43,44]$. Several 
participants had participated in exchange programs to other hosted universities in different regions of the United States. They suggested that the academic rigor and the learning motivations are not the same as their own colleges and universities [1,3,15,41]. One of the participants, Eddie, believed the low-motivation and low-expectation are due to the background of the university and the expectation of the university professors. However, more importantly, almost all participants expressed that their use of language, skin color(s), nationalities, and status of international student influenced their workload, use of services at schools, classmate attitudes, and even the balancing of classrooms at one of the historically black colleges and universities. For example, a participant expressed that they tended to provide less reading and lower-level assignments to international students due to their use of language and language proficiency. Although the lecturers and instructors did not directly express the discrimination, all participants had strong feeling of these events based on their personal characteristics $[43,44,59]$.

Previous literature $[3,11]$ suggested that international students usually have higher expectations and stronger background in academic expectations and achievements due to the selective admission criteria. Asian international students, however, usually receive better university admission exam scores and language test scores due to the long-term training and intensive secondary school education in their home countries. Therefore, in this case, when the international students enrolled at one of the historically black colleges and universities with less selective university admission and academic requirements, the expectations of these international students may not be met.

\section{Limitations and Implementations}

Each research study must have limitations and restrictions. The present study mainly focused on international students who enrolled and completed their undergraduate degree at one of the historically black colleges and universities in the United States. First, the numbers of participants were relatively small due to the limited background of historically black colleges and universities, and the enrollment of Chinese international students. Although the numbers of participants were limited, the researcher decided to employ the IPA methodology to seek in-depth understanding, background, lived stories, and sharing. It is worth noting that the IPA methodology successfully captured the essential information and findings to satisfy the gap between historically black colleges and universities, and Chinese international students $[47,48]$.

Second, the nature of understanding the problems of international students and historically black colleges and universities might be narrowed. However, the current literature and research database usually focus on international students who enrolled and completed their education at general and standardized American colleges and universities. It is worth noting that historically black colleges and universities always welcome the population of international students and students with different backgrounds and cultures. Although the limitation of historically black colleges and universities might be narrowed for research directions and results, the results and findings of this study are meaningful to understand and explore the current education problems for these particular groups of students and educational institutions.

Third, the benefits of this study are rich and colorful. Government agencies, policymakers, and related non-profit organization leaders may use this research study as a blueprint to establish connections, improve the minority policy, plans for international students, and intercultural assistance for minority people and students in the United States. Although the United States has encouraged social equalities and fairness for centuries, minority people and communities continue to face challenges and difficulties. The results of this research study indicated and explored the voices from international students at the college and university level.

Fourth, university leaders and administrators may benefit from this research study. Not only do historically black colleges and universities have the missions and goals to serve the minority people and communities in the United States, but regular and standardized educational institutions should also provide safe and equal environments for everyone in the country. Therefore, university counselling 
centers and offices for international students should pay attention to investigate the unfairness and bullying on campus.

\section{Future Studies}

The application of neo-racism was well used in this research study [42]. For future studies and research, scholars may employ the theory of neo-racism to understand and explore the experience and expectation of international students in the university environment. Due to the ideas of globalization, a large number of international students seek their education and career opportunities outside of their home country. Since the idea of neo-racism focuses on the place of origin and skin color(s) of individuals, future studies may explore the social problems of international students from different regions of the world.

Second, higher education institutions also involve a large number of international staff, professionals, research fellows, and instructors [33-35]. Besides the concerns for international students, staff from international locations may face similar problems on campus and in society. Therefore, future research may expand the lens from students to professional staff on campus.

Third, this research study focused on the experience and expectation of Chinese international students. Due to the uniqueness of both Chinese international students and traditionally black colleges and universities, the sample size was limited. In the future, scholars may expand the populations and research locations to cover larger populations [36]. For example, international students at historically black colleges and universities instead of Chinese international students.

Fourth, the lens may go beyond the location of historically black colleges and universities. This research intended to seek the unique experience and expectation from these targeted participants at the targeted higher education environment. However, scholars may change their scope due to the needs of their background and demands of society.

Funding: This research is based on support of 2019 Woosong University Academic Research Funding.

Conflicts of Interest: The authors declare no conflicts of interest.

\section{References}

1. Leong, P. Coming to America: Assessing the patterns of acculturation, friendship formation, and the academic experiences of international students at a U.S. college. J. Int. Stud. 2015, 5, 459-474.

2. Thompson, R. A qualitative phenomenological study of emotional and cultural intelligence of international students in the United States of America. J. Int. Stud. 2018, 8, 1220-1255. [CrossRef]

3. Knott, M. Overseas Students Up Slightly in USA. Available online: http://www.studytravel.network/ magazine/news/USA_international_students_SEVIS_May_2017 (accessed on 27 October 2018).

4. Lambert, J.R.; Basuil, D.A.; Bell, M.P.; Marquardt, D.J. Coming to America: Work visas, international diversity, and organizational attractiveness among highly skilled Asian immigrants. Int. J. Hum. Resour. Manag. 2017, 1-27. [CrossRef]

5. Chou, R.S.; Feagin, J.R. Myth of the Model Minority, 2nd ed.; Routledge: New York, NY, USA, 2015; ISBN 9781315636313.

6. Sherry, M.; Thomas, P.; Chui, W.H. International students: A vulnerable student population. High. Educ. 2010, 60, 33-46. [CrossRef]

7. Jung, E.; Hecht, M.L.; Wadsworth, B.C. The role of identity in international students' psychological well-being in the United States: A model of depression level, identity gaps, discrimination, and acculturation. Int. J. Intercult. Relat. 2007, 31, 605-624. [CrossRef]

8. Sümer, S.; Poyrazli, S.; Grahame, K. Predictors of depression and anxiety among international students. J. Couns. Dev. 2008, 86, 429-437. [CrossRef]

9. Wei, M.; Heppner, P.P.; Mallen, M.J.; Ku, T.-Y.; Liao, K.Y.-H.; Wu, T.-F. Acculturative stress, perfectionism, years in the United States, and depression among Chinese international students. J. Couns. Psychol. 2007, 54, 385-394. [CrossRef] 
10. Yakunina, E.S.; Weigold, I.K.; Weigold, A. Personal growth initiative: Relations with acculturative stress and international student adjustment. Int. Perspect. Psychol. Res. Pract. Consult. 2013, 2, 62-71. [CrossRef]

11. Myers-Walls, J.A.; Frias, L.; Kwon, K.; Ko, M.; Lu, T. Living life in two worlds: Acculturative stress among Asian international graduate student parents and spouses. J. Comp. Fam. Stud. 2011, 42, 455-478. [CrossRef]

12. Bodycott, P.; Lai, A. The role of Chinese parents in decisions about overseas study. In Understanding Higher Education Internationalization; Mihut, G., Altbach, P., Wit, H., Eds.; Sense Publishers: Rotterdam, The Netherlands, 2017; pp. 197-201.

13. Choudaha, R. Campus readiness for supporting international student success. J. Int. Stud. 2016, 6, I-V. [CrossRef]

14. Madge, C.; Raghuram, P.; Noxolo, P. Conceptualizing international education. Prog. Hum. Geogr. 2015, 39, 681-701. [CrossRef]

15. Jennings, R. International students at community colleges: Challenges and opportunities for this unique segment of U.S higher education. N. Dir. Stud. Serv. 2017, 2017, 61-71. [CrossRef]

16. Gordon, V.; Steele, G. The Undecided College Student: An Academic and Career Advising Challenge, 4th ed.; Charles, C., Ed.; Thomas Pub Ltd.: Springfield, IL, USA, 2015.

17. Curdt-Christiansen, X.L.; Wang, W. Parents as agents of multilingual education: Family language planning in China. Lang. Cult. Curric. 2018, 31, 235-254. [CrossRef]

18. Dos Santos, L.M. Foreign language learning beyond English: The opportunities of One Belt, One Read (OBOR) Initiative. In Silk Road to Belt Road; Islam, N., Ed.; Springer: Singapore, 2018; pp. 175-189.

19. Ke, I. Global English and world culture: A study of Taiwanese university students' worldviews and conceptions of English. J. Engl. Int. Lang. 2010, 5, 81-100.

20. Pan, L.; Block, D. English as a "global language" in China: An investigation into learners' and teachers' language beliefs. System 2011, 39, 391-402. [CrossRef]

21. Sun, H.; Steinkrauss, R.; Tendeiro, J.; De Bot, K. Individual differences in very young children's English acquisition in China: Internal and external factors. Biling. Lang. Cogn. 2016, 19, 550-566. [CrossRef]

22. Zhang, Y.; Tsang, M. Gender gap in the National College Entrance Exam performance in China: A case study of a typical Chinese municipality. Asia. Pac. Educ. Rev. 2015, 16, 27-36. [CrossRef]

23. Cruzvergara, C.Y.; Testani, J.A.; Smith, K.K. Leadership competency expectations of employers and the expanding mission of career centers. N. Dir. Stud. Leadersh. 2018, 2018, 27-37. [CrossRef]

24. Lucas, C. American Higher Education: A History; Palgrave Macmillan: New York, NY, USA, 2006.

25. Wang, K.; Heppner, P.; Fu, C.; Zhao, R.; Li, F.; Chuang, C. Profiles of acculturative adjustment patterns among Chinese international students. J. Couns. Psychol. 2012, 59, 424-436. [CrossRef]

26. Wang, S.; Kim, B. Therapist multicultural competence, Asian American participants' cultural values, and counseling process. J. Couns. Psychol. 2010, 57, 394. [CrossRef]

27. Yeh, C.; Inose, M. International students' reported English fluency, social support satisfaction, and social connectedness as predictors of acculturative stress. Couns. Psychol. Q. 2003, 16, 15-28. [CrossRef]

28. Du, Y.; Wei, M. Acculturation, enculturation, social connectedness, and subjective well-being among Chinese international students. Couns. Psychol. 2015, 43, 299-325. [CrossRef]

29. Zhang, Y. International students in transition: Voices of Chinese doctoral students in a U.S. research university. J. Int. Stud. 2016, 6, 175-194.

30. King, B.; Gardiner, S. Chinese international students: An avant-garde of independent travellers? Int. J. Tour. Res. 2015, 17, 130-139. [CrossRef]

31. Zhang, H.; Zhou, Y.; Stodolska, M. Socio-cultural adaptation through leisure among Chinese international students: An experiential learning approach. Leis. Sci. 2018, 1-20. [CrossRef]

32. Sun, P.; Liu, B.; Jiang, H.; Qian, F. Filial piety and life satisfaction among Chinese students: Relationship harmony as mediator. Soc. Behav. Personal. Int. J. 2016, 44, 1927-1936. [CrossRef]

33. Gasman, M. Perceptions of black college presidents. Am. Educ. Res. J. 2011, 48, 836-870. [CrossRef]

34. Brown, M.; Donahoo, S.; Bertrand, R. The black college and the quest for educational opportunity. Urban Educ. 2001, 36, 553-571. [CrossRef]

35. Palmer, R.; Maramba, D. Racial microaggressions among Asian American and Latino/a Students at a historically black university. J. Coll. Stud. Dev. 2015, 56, 705-722. [CrossRef]

36. Brux, J.; Fry, B. Multicultural students in study abroad: Their interests, their issues, and their constraints. J. Stud. Int. Educ. 2010, 14, 508-527. [CrossRef] 
37. Kim, E.; Aquino, K.C. Thwarting or embodying model minority stereotypes. In Modern Societal Impacts of the Model Minority Stereotype; IGI Global: Hershey, PA, USA, 2015; pp. 155-184.

38. Sakurai, Y.; Parpala, A.; Pyhältö, K.; Lindblom-Ylänne, S. Engagement in learning: A comparison between Asian and European international university students. Comp. A J. Comp. Int. Educ. 2016, 46, 24-47. [CrossRef]

39. Kim, D.; Bankart, C.; Jiang, X.; Brazil, A. Understanding the college choice process of Asian international students. In Understanding International Students from Asia in American Universities; Springer International Publishing: Cham, Switzerland, 2018; pp. 15-41.

40. Harper, S.R. Black male college achievers and resistant responses to racist stereotypes at predominantly white wolleges and universities. Harv. Educ. Rev. 2015, 85, 646-674. [CrossRef]

41. Hamer, J.F.; Lang, C. Race, structural violence, and the neoliberal university: The challenges of inhabitation. Crit. Sociol. 2015, 41, 897-912. [CrossRef]

42. Lee, J.; Jon, J.; Byun, K. Neo-racism and neo-nationalism within East Asia. J. Stud. Int. Educ. 2017, 21, 136-155. [CrossRef]

43. Lee, J. International students' experiences and attitudes at a US host institution: Self-reports and future recommendations. J. Res. Int. Educ. 2010, 9, 66-84. [CrossRef]

44. Lee, J.; Rice, C. Welcome to America? International student perceptions of discrimination. High. Educ. 2007, 53, 381-409. [CrossRef]

45. Merriam, S.B. Qualitative Research: A Guide to Design and Implementation; Jossey Bass: San Francisco, CA, USA, 2009.

46. Creswell, J. Qualitative Inquiry and Research Design: Choosing among Five Approaches; Sage: Thousand Oaks, CA, USA, 2012.

47. Smith, J.; Flowers, P.; Larkin, M. Interpretive Phenomenological Analysis: Theory, Method, and Research; Sage: Thousand Oaks, CA, USA, 2009.

48. Smith, J.; Osborn, M. Interpretative phenomenological analysis. In Qualitative Psychology: A Practical Guide to Methods; Sage: London, UK, 2003.

49. Tang, K.H.; Dos Santos, L.M.A. Brief discussion and application of interpretative phenomenological analysis in the field of health science and public health. Int. J. Learn. Dev. 2017, 7, 123-132. [CrossRef]

50. Brocki, J.M.; Wearden, A.J.A. Critical evaluation of the use of interpretative phenomenological analysis (IPA) in health psychology. Psychol. Health 2006, 21, 87-108. [CrossRef]

51. Thomas, D.R.A. general inductive approach for analyzing qualitative evaluation data. Am. J. Eval. 2006, 27, 237-246. [CrossRef]

52. Creswell, J. Qualitative Inquiry and Research Design: Choosing Among Five Approaches; SAGE Publications: Thousand Oaks, CA, USA, 2007.

53. Dos Santos, L.M. How do teachers make sense of peer observation professional development in an urban school. Int. Educ. Stud. 2016, 10, 255. [CrossRef]

54. Pierson, H. Cantonese, English, or Putonghua: Unresolved communicative issue in Hong Kong's future. In Education and Society in Hong Kong: Toward One Country and Two Systems; Postiglione, G.A., Leung, Y.M., Eds.; Routledge: London, UK, 2018; pp. 183-202.

55. Lee, J.S.; Lee, K. Perceptions of English as an international language by Korean English-major and non-English-major students. J. Multiling. Multicult. Dev. 2019, 40, 76-89. [CrossRef]

56. Dos Santos, L.M. Evaluation of a foreign language textbook used in the Greater Boston Region: An evaluation of a Japanese as a foreign language textbook. Int. Res. Educ. 2017, 5, 152-161. [CrossRef]

57. Dos Santos, L. The cultural cognitive development of personal beliefs and classroom behaviours of adult language instructors: A qualitative inquiry. Brain Sci. 2018, 8, 220. [CrossRef] [PubMed]

58. Sheehan, B.; Derlega, V.; Maduro, R.; Winstead, B. Prior experiences with racial discrimination predict psychological reactions to a recent incident of race-based rejection among African American university students. J. Loss Trauma 2019, 24, 115-128. [CrossRef]

59. Dos Santos, L.M. Career decision of recent first-generation postsecondary graduates at a metropolitan region in Canada: A social cognitive career theory approach. Alta. J. Educ. Res. 2018, 64, 141-152.

(C) 2019 by the author. Licensee MDPI, Basel, Switzerland. This article is an open access article distributed under the terms and conditions of the Creative Commons Attribution (CC BY) license (http://creativecommons.org/licenses/by/4.0/). 